\title{
TRANSLATION: TREASON, SERENDIPITY OR ACQUIRED INSTINCT?
}

\author{
Patrick John O Sullivan \\ Universidade Católica de Goiás \\ patanne@terra.com.br
}

\begin{abstract}
This article reviews Gregory Rabassa's memoirs called "If this be treason". It pays tribute to a brilliant translator and literary critic, who is one of the unsung heroes of Spanish and Portuguese Literature. His memoirs, enriched by years of experience and theoretical reflection, provide a profound and wonderfully readable meditation on the art of translation, without ever becoming pedantic. They are divided into three sections: a) the translator, b) the translated and, finally, c) his verdict on the treason involved in the translation process. In this article, Aubert's (1997) translation modalities are used to analyze Rabassa's strategies when dealing with culture-specific items.
\end{abstract}

Keywords: Gregory Rabassa, Brazilian Literature, Latin American Literature, translation, translator.

\section{Introduction}

"Publish or Perish" is how McLuhan, media guru e social critic of the 60s, characterized the fervour of certain university professors in 1951 in a letter to Ezra Pound (Molinaro et al., 1987, p. 226). If he were writing today he would probably say Publish IN ENGLISH or Perish! The situation in international publishing is almost totally dominated by English language publications. Lepape (2004) reports that less than $3 \%$ of the 14,000 books published in UK every year are translations and of US publications only $2.8 \%$ 
are translations. French publishers only translate from English, with only two exceptions - Paulo Coelho and Umberto Eco. With a few exceptions, Americans publishing houses say they simply have no room on their shelves for "slow-sellers and foreign books"(Lepape, 2004, p.15).

That is why as far back as 1990, the Sociedade Brasileira para o Progresso da Ciência made the controversial decision to recommend research publication in English - and since then, engineers, dental surgeons and doctors have been publishing their research through the medium of English. This is their only chance of being read in the rest of the world.

\section{Gregory Rabassa, literary translator}

The superbly-honed musical language of literature, often loaded with cultural and local references, poses a special challenge to the translator. Robert Frost's definition of poetry as "what is lost in translation" has been quoted endlessly and equally Virginia Woolf showed her scepticism about being translated when she wrote, "humour is the first of the gifts to perish in a foreign tongue" (2004, p. 57). Pinheiro (2003, p. 343) quotes the Spanish philosopher Gasset, who considers the act of translation "a utopian exercise" and even goes so far as to say that "everything worthwhile, everything truly human is difficult, very difficult; so much so, that it is impossible", but concludes "to declare its impossibility is not an argument against the possible splendour of the translator's task" (Gasset, p. 99-100). The origin of this "splendour", which succeeds in transmitting intangible, wordless, barely-suggested ideas and musicality in the source text, is sought out in the recently-published memoirs of Gregory Rabassa, the renowned literary translator.

Rabassa was responsible for translating over 60 books by 27 authors, including Jorge Amado, Machado de Assis and other Brazilian writers. But by far his most famous translation was One Hun- 
dred Years of Solitude, of which the author, Gabriel Garcia, is reported to have said that the English version is superior to his original Spanish. Not only did Rabassa himself translate authors from ten different countries, but he also encouraged his students at Columbia University to do so. Together this group must be considered responsible for an invaluable contribution to the literary movement called the Latin American Boom, which began in the 1970s (Levinson, 2001).

\section{2. "Memories are made of this"}

Rabassa divides his memoirs into three main parts:

1. The translator

2. The translated

3. The verdict.

\subsection{The translator}

He begins his memoirs by drawing attention to the famous Italian adage traduttore, traditore (translator, traitor) and looks at the many facets of the translator's treason. "The important thing is consider whether the treason is high or low, the sin mortal or venial" (p. 8). In other words, treason could be the so-called act of high treason for betraying one's country or equally it could be the low treason of a misdemeanor. Rabassa teases out three relevant dimensions of the idea of treason or betrayal.

The first most elementary treason is the betrayal of words - but then words are loaded with feelings or packed with cultural references and how can one communicate such nuances? How can one be sure that what the word 'stone' represents in English corresponds to what pedra means in Portuguese? One would certainly be left in doubt if you tried to translate Gil Perini's 'A Pedra' (Perini, 1999) as 'The Stone', where perhaps 'The Nugget' might better express the core of the story. 
Secondly, there is the betrayal of the author who is being translated. "Can we ever feel what the author felt as he wrote the words we are transforming?" (p. 4), Rabassa asks. We know that every reader has his/her own interpretation of a work, but the translator's reading has to go beyond a mere personal reading, because it, in turn, will determine how new readers will interpret the work.

And thirdly, we could even betray ourselves in the process of translation by, for example, transferring our ideological or cultural ideas onto the author's text. The translator too has his own culture and is quite often an outsider whereas the author writes from within his own culture, merging words, language and symbols in a way only $\mathrm{s} / \mathrm{he}$ understands. This can be treacherous territory. The opposite can also be true, of course, as witnessed by the recently acclaimed Chinese writer, Yiyun Li. Commenting on the fact that the Chinese language has no vocabulary to talk about feelings within the family, she says "I feel just so much more comfortable writing in English. I need a distance with language to write" (Edemariam, 2006).

Rabassa is humble about his getting involved with translation but leaves no doubt about where he acquired some of the expertise and skill needed for the art of translating. He claims that even though "[I] sort of backed into translation without having thought about it or having set my sights on it, I do have within me certain ingredients, innate or circumstantial, that could be said to have tilted me in that direction" (p. 29). Born of a Cuban father and an American mother who in turn had Spanish and British forebears, he was brought up playing with words and language. Funnily enough, he didn't learn Spanish at home, because his father wanted to improve his own fluency in English. Rabassa's formal education involved learning Latin, French, Spanish and Italian. The language-learning methodologies used before the 60s, especially the so-called GrammarTranslation or Classical Method (Larsen-Freeman, 2000; Howatt, 1984), involved frequent use of translation. Rabassa himself confirms the practice of translation in language learning when he says, "All through school and college I was doing translation, as it was an important ingredient in language study in those days" (p. 34). 
Drafted into the Army during the War, he learned cryptography and was posted to Algiers and later to Italy. And it was in the army, he claims, that his vocabulary was really enriched, especially the bawdy, earthy breed of language with all its sexual undertones and overtones. This, he jokes, served him well when it came to translating Jorge Amado's cattle drovers' swearing!

\subsection{The translated}

\subsubsection{Brazilian authors}

Though Rabassa's most famous translations are Garcia's One Hundred Years of Solitude and Cortázar's Hopscotch, this text will confine itself to what he himself described as his 'fascination' for Brazil. For his doctoral thesis he researched black characters in Brazilian fiction, mostly in Jorge Amado's works. Later he took up a post at Columbia University and began translating Spanish and Portuguese writers.

In 1962, with a summer fellowship to collect books in Brazil, he visited Belém and then Recife, where he met Gilberto Freyre as well as Nélida Piñon. From there he journeyed to Bahia, where he got a 'non-tourist' taste of Afro-Brazilian culture ("before candomblé and capoeira became Disneyfield"!) and visited some of the places frequented by Jorge Amado, whom he only met in person much later. He traveled to Rio where, among others, he met Antônio Houaiss and Dalton Trevisan.

At the time of his arrival in Brazil, the two works being discussed in literary circles were Guimarães Rosa's Grande Sertão: Veredas and Clarice Lispector's A Maçã no Escuro. He was invited to translate this work by Lispector and admits how happy he was to have escaped Guimarães Rosa's work and explains “Clarice goes smoothly into English, Rose would have to be re-written, not translated, unless by the likes of James Joyce" (p. 71). He found Clarice wrote with a "clear, flowing evocative style", and was obviously impressed by her - "she looked like Marlene Dietrich and wrote like Virginia Woolf"(p. 70)! And one nice little touch 
about his translation of Lispector's work was that the editors put the translator's name on the dust jacket. Being such a rare occurrence, that really pleased him.

On that first Brazilian trip he also picked up Dalton Trevisan's Novelas Nada Exemplares and translated some of his "stark magic realistic stories" for publication in magazines. He compares him to Machado de Assis and laments the lack of attention that both of these have received from outside Brazil. The same is true of Lima Barreto, whose story The Man Who Knew Javanese he translated for inclusion in the Oxford Book of Latin American Short Stories.

His next incursion into Brazilian translation was to work on Afrânio Coutinho's Introdução à Literatura no Brasil. Until then he had concentrated on the translation of fiction and while he found Coutinho's book “intelligent, original and well-written" (p. 82), the language of literary criticism bored him somewhat. But this experience of getting to know Brazilian literature was to be very useful when translating other Brazilian writers because, through it, he had grasped the broader context. He was also happy to have done this translation for his friend, Afrânio Coutinho, and also because "big old Brazil sits there ignored [...] and has a very worthy intellectual side to offer us" (p. 84).

And just as Pablo Neruda describes how 'poetry arrived in search of me', so too it arrived at Rabassa's reluctant doorstep. On his own admission, Rabassa's effort to translate Venícius de Moraes' poetry was not very successful. He loves 'Creation Day' in which Vinícius suggests that God should have rested on the sixth day, hinting that the origin of this idea might be found in Machado de Assis and marvels at the Brazilian way of dealing with such a topic. In the context of translating poetry, he claims that reading poetry with even a beginner's knowledge of the language is better than reading it in translation.

Throughout his memoirs, Rabassa reveals some of the 'secrets' of translation, and in his inimitable, witty style demonstrates the importance of knowing the background, setting, character types, style of humor, as well as the two languages and cultures involved. 
A number of Jorge Amado's works had already been translated when he was invited to undertake Mar Morto. He believes that his own knowledge of Jorge Amano's Bahias, both the city (sic - he claims that only the initiated understand the reference to the "city of Bahia', otherwise Salvador!) and the south of the State, helped bring his translation to life. In all, he translated four of Jorge Amado's works. He talks of the difficulty of translating slang as well as the references to Afro-Brazilian religion. He attributes some of his success to Jorge Amado for having "lighted a candle on the beach in honour of Iemanjá for me" (p. 134).

On writing a book called $A$ Death in Brazil about the death of PC Farias, Peter Robb (2004) immersed himself in conflicting identities in Brazil, between the Northeast and South, between Lula and Collar, between the modern and the remnants of slavery. While contributing to rekindling international interest in Machado de Assis he says: "The major novels of Machado de Assis, The Posthumous Memoirs of Bras Cubas, Quincas Borba, Dom Casmurro, and Esau and Jacob, have all been newly translated in a wonderfully exact and readable way at last for Oxford's Library of Latin American. All of the above translations are excellent..." (p.309). Of these, the first two were translated by Gregory Rabassa, who claims that despite having received considerable praise for his many translations, "it wasn't until I did two of Machado de Assis's masterpieces that I felt fulfilled as a translator"(p. 157). He felt that the earlier translations were acceptable but had been given the "asinine' titles of Epitaph of a Small Winner and Philosopher or Dog?.

Through one of his colleagues at Columbia University, Rabassa was persuaded to translate Darcy Ribeiro's $O$ povo brasileiro, which, unfortunately, Darcy did not live to see. Rabassa's student had translated Darcy's fictional novels, Maira and The Mule, and asked him to translate the anthropological study of Brazil. Because of his interest in things Brazilian he was fascinated by Darcy Ribeiro's theories about Brazilian society and the differences between Brazilian Portuguese and that of the mother country. 
One of José Sarney's aides asked Rabassa to translate $O$ Dono do Mar, an account of the lives of fishermen on the coast of Maranhão. While writing his memoirs Rabassa was working on the translation of Saraminda, set in Amapá.

\subsubsection{Culture-specific items (CSIs)}

Rabassa shows a special flair for dealing with what Aixelá (1996) called 'culture-specific items (CSI)'.These include proper nouns such as, place names, street names and personal names, as well as cultural expressions. Aixelá (1996) claims: "The first problem we face in the study of cultural aspects of translation is how to devise a suitable tool for our analysis, a notion of 'culture-specific item' (CSI) that will enable us to define the strictly cultural component as opposed to, say, the linguistic or pragmatic one" (pp. 56-57).

While the art of translation cannot be reduced to translating 'items', undoubtedly, the advances in machine-assisted translation has led to a concentration on this particular aspect. As Aubert (1995, p. 1) said: "in the everyday work of professional translators, translation is (or is felt to be) very much a word-centred operation, resorting to diction-aries, thesauri, and the like as the primary external tool in their daily work. Indisputably, this is not the entire truth; far from it. But one might perhaps dare to suggest that it is a significant part of the per-ceived truth".

In order to help analyze the degree of difference and proximity between two texts - the original and translation - Aubert (1997) worked out a 'translation modalities differentiation scale', which, according to Validório \& Camargo (2005), is a "reformulation of the model proposed by Venay \& Darbelnet $(1958,1977,1995)$ ". The most-commonly used include omission, loan, literal translation, transposition, explicitation/implicitation, modulation and adaptation. In some situations, two or more of these translation modalities can be combined to clarify a particular situation. Some of Rabassa's solutions to translating book titles as well as some culture-specific items will be analyzed using Aubert's translation modalities. 


\subsubsection{Book titles:}

Mar Morto: This was the first of Jorge Amado's books to be translated by Rabassa. He notes that the "obvious biblical connotation" (p. 134) of calling it 'Dead Sea' would not be appropriate in English and opted for Sea of Death, which expressed the spirit of the story. Following Aubert's (1997) classification, 'Dead Sea', the literal translation, is avoided in favor of transposition, where a morpho-syntactical adaptation as well as a change in word order have been made to avoid cultural transference. Validório e Camargo (2005) have analyzed Rabassa's translation of 'Dead Sea' and point out how he uses Aubert's modulation modality to enrich the sensorial experience of reading Jorge Amado.

Tocaia Grande: Rabassa explains that the name, literally 'Big Ambush', was that of a settlement, which grew into a large town, and claims: "That original name would have meant nothing to the American reader so the editors opted for something a little more understandable and one that does convey a good deal of the spirit of the novel" (p. 153). They chose Showdown which carries the message of a confrontation, which is the general idea. Interestingly enough, here Rabassa clarifies that the book title, which Aubert's translational modality in use here is an adaptation, not a direct equivalence, but an effort to convey the meaning of the original.

Cien años de soledad:Rabassa states that in Spanish the word soledad encompasses both the more positive 'solitude' as well as the more negative 'loneliness' of the English. As the English required an indefinite article, he opted for the title $A$ Hundred Years of Solitude.

O Dono do Mar: While considering the literal translation "a bit drab" (p. 181), he decided on Master of the Sea for Sarney's novel, as yet unpublished. Peter Robb (2004, p. 289) mentions Raymundo Faoro's famous book, Os Donos do Poder, calling it 'The Owners of Power'. For such an impressive tome, the title 'The Masters of Power' would certainly seem more appropriate. 


\subsubsection{Certain culture-specific items}

Certain Brazilian Portuguese words, such as, samba, cerrado, lambada and feijoada are slowly being incorporated into English and have been recognized by recent editions of the Oxford Dictionary. To translate the different Brazilian currencies, Rabassa suggests a biblical-type solution. After all, Jesus was sold for thirty piece of silver, which would not convert easily into dollars or euros! So Rabassa suggests the older word conto, with monetary references both in Portugal and Brazil, to include the cruzeiro, cruzado, novo cruzado and real. Using Aubert's (1997) translation modalities, this option would be categorized as a loan, enriched by modulation. For Rabassa, "it is an unofficial designation and simply means a thousand of whatever the currency happens to be at the moment" (p. 168).

On the question of addresses, he thinks that the solution more often than not is to preserve the original. In the case of praça, for example, he thinks that most Americans would not know its meaning and that plaza suggests something closer to shopping malls. In the case of a proper noun he opts for Aubert's (1997) loan modality, reproducing the name as in Portuguese, but where it appears as a common noun, he opts for the literal translation, square.

As regards cachaça, the Brazilian national drink can be translated as aguardiente or raw rum but he prefers cane liquor, though he feels Americans are becoming more familiar with Brazil and many would recognize the main ingredient of a caipirinha. The use of 'cane liquor' to translate cachaça would be categorized as an explicitation in Aubert's translation modalities.

For descriptive words, such as caipira or matuto, which carry regional nuances, his solution is to maintain the words and add a few words of explanation for the reader's benefit. This translation modality involves a loan, enriched by an explicitation (Aubert, 1997).

In the case of words which have already been used in previous translations and acquired certain references in the mind of the English-language reader, such as backlands for sertão, in both 
Guimarães Rose and Euclides da Cunha, he prefers to maintain these same words.

\subsection{The verdict}

This article set out to give a taste of the richness of Rabassa's reflections on the art of translation. Today, as a Distinguished Professor of Romance Languages and Comparative Literature at Queens College, New York, although well versed in translation theory, in his memoirs he confines himself largely to describing his experience with the authors and their books. His best-known translations are from the Spanish, but this article limits itself to reporting on his translations of Brazilian novelists and poets, as well as his incursions into literary theory and anthropology. Languages can only be 'imitated', he claims, never 'cloned' but the translator will always need an acute 'cultural instinct' to do justice to the source text. He discusses how he approaches 'culture-specific items', without using the term, and here we have invoked Aubert's (1997) analysis to help understand his options.

At the advanced age of 84, Rabassa casts a cold eye on his life and the treachery of translation and pronounces his verdict: - "translation can only approach the possible and never get there" (p.188). He expresses his "ultimate dissatisfaction" with all of his work, but for his contribution to making Latin American literature accessible to millions of people, we must be eternally grateful.

\section{Bibliography}

AUBERT, F.H. (1995) "Translation theory, teaching and the profession". In Perspectives: Studies in Translatology. Copenhagen, Museum Tusculanum Press. 
Available at < http://www.duo.uio.no/roman/Art/Rf6-97-2/Aubert.doc > . Acessed 15/02/08.

AUBERT, F.H 'Translation Modalities - A Descriptive Model for Quantitative Studies in Translatology' (1997) In Romansk Forum 6. Oslo: University of Oslo. Available at < http://www.duo.uio.no/roman/Art/Rf6-97-2/Aubert.doc $>$. Acessed $15 / 02 / 08$.

AIXELÁ, J.F. 'Culture-specific Items in Translation'. IN: RODRIGUES, R.A; VIDAL, M.C-A Translation, Power, Subversion. (Topics in Translation 8). Cleavedon: Multilingual Matters. 1996. pp. 52-78.

EDEMARIAM, A. 'Found in Translation. An Interviw with Yiyun Li'. The Guardian Weekly, 15- 21 December, 2006. vol. 175 Nº. 26.

HOWATT, A.P.R. A History of English Language Teaching. Oxford University Press. 1984.

LARSEN-FREEMAN, D. Techniques and Principles in Language Teaching. Oxford University Press. 2000.

LEPAPE, P. 'Lost without translation: English-language books dominate world publishing'. (trans. Gulliver Gragg). Le Monde Diplomatique, May 2004.

LEVINSON, B. The Ends of Literature: The Latin American "Boom" in the Neoliberal Marketplace, Stanford: Stanford University Press. 2001.

MOLINARO, M; McLUHAN, C; TOYE, W. (eds.). The Letters of Marshall McLuhan. Toronto. Oxford University Press, 1987.

NERUDA, Pablo. Poetry. <www.poemhunter.com > accessed on 12/12/2005.

GASSET, José Ortega YT. 'The Misery and Splendour of Translation'. IN: Schulte, R.; Biguenet, J. Theories of Translation: An Anthology of Essays from Dryden to Derrida. Chicago \& London: The University of Chicago Press. 1992. 
PERINI, G. O pequeno livro do Cerrado. São Paulo: Editora Giordinao. 1999.

PINHEIRO, B.da Silveira. 'Translating Joyce'. IN: ABEI Jornal - The Brazilian Journal of Irish Studies. Interrelations. Number 5. São Paulo-SP: FFLCH/USP. 2003. p. 343-349.

RABASSA, G. If this be treason: Translation and Its Dyscontents. New Directions: New York, 2005.

ROBB, P. A Death in Brazil. Bloomsbury Publishing. 2004.

RODRIGUES, R.A; VIDAL, M.C-A Translation, Power, Subversion. (Topics in Translation 8). Cleavedon: Multilingual Matters. 1996.

SCHULTE, R.; BIGUENET, J. Theories of Translation: An Anthology of Essays from Dryden to Derrida. Chicago \& London: The University of Chicago Press. 1992.

VALIDÓRIO, V.C.; CAMARGO, D. C. de. 'Um Estudo da Tradução de Termos Culturalmente Marcados em O Sumiço da Santa: The War of The Saints e Mar Morto: Sea Death, de Jorge Amado, Traduzidas por Gregory Rabassa'. Estudos Lingüísticos XXXIV. São Paulo: USP. 2005. p. 1349-1354. Available at $<w w w . g e l . o r g . b r / 4$ publica-estudos-2005 > . Accessed on 12/02/08.

WOOLF, V. The Common Reader. First Series.(first published in 1925). ebooks@Adelaide. Australia. 2004. 